\title{
Study Of Parthenium hysterophorus L. Extracts (First clean-up Fractions) On Seed Germination Behaviour In Search Of Bioactive Fractions for Preparation of Bioherbicide Formulations.
}

\author{
Ujjal Kumar Pati ${ }^{1 a *}$, Ashim Chowdhury ${ }^{1 \mathrm{~b}}$ \\ ${ }^{1}$ Department of Agricultural Chemistry \& Soil Science, IAS, University of Calcutta, 35-B.C. Road, \\ Kolkata - 700019, India \\ email address: ${ }^{a}$ ujjalkrpati@gmail.com, bashimchowdhry@gmail.com \\ ${ }^{*}$ Corresponding author: email address ujjalkrpati@gmail.com
}

Keywords: Parthenium, ethylacetate, methanol, germination indices, cellular respiration

\begin{abstract}
Increase in productivity is directly related with increase pesticide consumption. So there is a strong desire to use "greener" chemistry to produce more toxicologically and environmentally benign pesticides and natural products. In this present study, a comparison was made to evaluate the phytotoxicity potential of first cleanup fractions obtained from sequentially extracted solvent (ethyl-acetate, methanol) extracts of Parthenium hysterophorus L. (aerial parts) in vitro through bench-top seed germination assay (Vigna radiata L.). One-way analysis of variance (ANOVA) followed by Duncan's multiple range test (DMRT) were done for statistical analysis of the data. The study reveals that germination, growth and vigour was significantly $(\mathrm{P}<0.05)$ reduced by ethyl-acetate and methanol fractions. A significant changes in soluble and insoluble sugar content, protein, amino acid content and cellular metabolic activity was aslo observed by $1 F 3,1 F 4$, $1 F 6$, and $1 F 9$ fractions. The present study concluded that phytotoxicity of four fractions $(1 F 3,1 F 4$, $1 F 6$, and $1 F 9$ ) from ethylacetate and methanolic crude extracts of Parthenium hysterophorus could be exploited as potential bioherbicide for future weed management programme and the development of bioherbicide for commercial use.
\end{abstract}

\section{INTRODUCTION}

With the advancement of civilization, mankind has two primary goal in mind - (i) achieving food security and (ii) improving the quality of life. To achieve the earlier point we always ignore our traditional resources and relied on the synthetic agrochemicals for productivity increase and pest management. Today, more than $60 \%$ of our population is involved in agriculture sector, which dominates the economic scenario of our country. The increasing pattern of productivity is directly related with increasing trend of pesticide consumption

Due to favourable growth and multiplication criteria offered by a tropical country like India pests (insects, fungal pathogens, nematodes, weeds, rodents, birds, mollusc etc.) assume a serious proportions throughout the year. Year round cropping system also encourage these pest populations. So, losses due to pests are far greater than the temperate countries. Crop reduction due to pests accounts for $25-35 \%$. This has been a reason for intensive use of pesticides.

Natural product especially plant product is used as the one of main sources of biocides as pharmaceuticals, crop protection chemicals and many more since time immemorial. Many highly effective chemicals have so far been isolated from plant sources especially as pest control agents viz., nicotine, pyrethrins, cinerins, rotenone, ryanodine etc. [1]. In recent times number of breahthrough work has been done in respect of biopesticides with particular reference to botanicals, microbial pesticides, pheromones, IGR, plant growth regulators, and new more promising crop protection molecules. A detailed review of naturally occurring bioactive crop protecting chemicals has been discussed by Vyvyan [2] and Dyan [3,4].

However, in today's perspective, there is a strong desire to use "greener" chemistry to produce more toxicologically and environmentally benign pesticides and natural products. Natural products, especially phytochemicals have been the potential source of many pesticides, either used directly as 
crude preparations or as pure compounds. They have been used more often as structural leads for the discovery and development of natural product-based pesticides.

There are several examples of plants used as fungicides, insecticides, molluscicides, algaecides and other pesticides than as herbicides [2]. Among the weeds Parthenium hysterophorus L., is an aggressive weed native to Southern North America, Central America, the West Indies and Central South America, having allelopathic effect and drastically retards the growth of many species [5]. Parthenium is an invasive exotic weed commonly known as Bitter weed, false ragweed, Fever few, Ragweed, Carrot weed, White top, Chatak chandani, Congress grass \& Star weed. Its botanical name is Parthenium hysterophorus L. and belongs to the Class: Magnoliopsida, Family: Asteraceae (Compositae). It is an annual herb and has a deep taproot and erect stem, which becomes woody with age. Height varies of Parthenium weed between $50-150 \mathrm{~cm}$, leaves are deeply lobed. It is pale green in colour and has soft hair. Flower are creamy white in color. It has small (1-2mm long) black seeds with white scales. They are not visible to the naked eye. The countries where it has been reported are South Africa, Mozambique, Madagascar in Africa, China, India, Vietnam, Nepal in Asia, Guatemala, Honduras, Belie etc. in Central America, Mexico, in South America and in United States [cf. 6].

The invasive nature of the noxious weed P. hysterophorus L., is thought to be due to an ability to displace other species by means of allelopathy. The allelochemicals released from Parthenium affecting many plant species are sesquiterpene lactones and phenolics. Parthenin is the major sesquiterpene lactone whereas caffeic, vanillic, ferulic, chlorogenic and anisic acids are the major phenolics [5,7]. These two synergistically acting groups of allelochemicals significantly decrease the seed germination and subsequent growth in many crops [7]. Therefore, current study was undertaken to investigate and identify the phytotoxic fractions of the ethylacetate and methanol crude extracts of Parthenium hysterophorus L. on germination and early seedling growth of test plant species under laboratory conditions.

\section{MATERIAL AND METHODS:}

Plant material for extraction: The plant sample (Parthenium hysterophorus L) was collected from local vegetation of Baruipur, 24-Paraganas (south) [22 $21^{\prime} 29^{\prime} ' \mathrm{~N}$ Latitude and 88 $26^{\prime} 37^{\prime}$ ' $\mathrm{E}$ Longitude and altitude of 42 feet], West Bengal (W.B.), India. The samples were cut into small pieces, air dried at room temperature $\left(25 \pm 30^{\circ} \mathrm{C}\right)$, then oven dried for 2 days at $40^{\circ} \mathrm{C}$ and powdered by mechanical grinder to store in air tight packets which are now ready for experiment.

Seed material for bioassay: Vigna radiata L. Seeds were used in this experiment as target organism for bioassay. The seed materials were procured from the Department of Agronomy, BCKV, Mohanpur, Kalyani, Nadia (W.B.), India.

Extraction: $100 \mathrm{~g}$ of powdered Parthenium was sequentially extracted with solvents $(600 \mathrm{ml})$ of increasing polarity [6]. This process were repeated several times till the experiment completed.

Isolation for cleanup: Isolation for clean-up of the crude extracts (Ethyl acetate and Methanol crude extract) was then subjected to liquid column chromatography on silica gel G (Merck 60-100 mesh) as adsorbent following solvent of increasing polarity. The elution was done with solvents wef $100 \%$ hexane to $100 \%$ methanol as eluent of increasing polarity with two gradients. Elutes, as fractions $(200 \mathrm{ml}$ each) were collected and marked accordingly (Table- 1$)$. The fractions were then concentrated on rotary vacuum evaporator (Buchi type) and were subjected to phytochemical analysis and bioassay. 
TABLE-1: Results of the column chromatography of the Ethyl acetate and Methanol extract of Parthenium hysterophorus by increasing polarity:

\begin{tabular}{|c|c|c|c|c|}
\hline \multirow{2}{*}{ Sovents \& mixture } & \multicolumn{2}{|c|}{ From ethylacetate crude } & \multicolumn{2}{|c|}{ From methanol crude } \\
\hline & $\begin{array}{c}\text { Residues/fractions on } \\
\text { evaporation }\end{array}$ & $\begin{array}{c}\text { Name of the } \\
\text { cleanup fractions }\end{array}$ & $\begin{array}{c}\text { Residues/fractions on } \\
\text { evaporation }\end{array}$ & $\begin{array}{c}\text { Name of the cleanup } \\
\text { fractions }\end{array}$ \\
\hline Hexane $(100 \%)$ & Fraction 1 & $1 F 1$ & Fraction 6 & $1 F 6$ \\
\hline Hexane: Ethyl acetate $(1: 1)$ & Fraction 2 & $1 F 2$ & Fraction 7 & $1 F 7$ \\
\hline Ethyl acetate $(100 \%)$ & Fraction 3 & $1 F 3$ & Fraction 8 & $1 F 8$ \\
\hline Ethyl acetate: methanol $(1: 1)$ & Fraction 4 & Fraction 9 & $1 F 9$ \\
\hline Methanol $(100 \%)$ & Fraction 5 & $1 F 5$ & Fraction 10 & $1 F 10$ \\
\hline
\end{tabular}

Phytochemical analysis: The qualitative tests [8] were used for detecting the presence of various phytochemicals to give general idea of chemical constituents present in various fractions as per the Table-2.

TABLE-2: Qualitative tests for phytochemical constituents

\begin{tabular}{|c|c|c|c|}
\hline Secondary metabolites & Name of the test & Methodology & Observation \\
\hline \multirow[t]{2}{*}{ Alkaloides } & Mayer's test & $\begin{array}{l}\text { To } 1 \mathrm{ml} \text { of extract, } 1 \mathrm{ml} \text {. of Mayer's reagent } \\
\text { was added (Potassium mercuric iodide } \\
\text { solution). }\end{array}$ & $\begin{array}{l}\text { Whitish or cream } \\
\text { colour precipitated }\end{array}$ \\
\hline & Wagner's Test & $\begin{array}{l}\text { To } 1 \mathrm{ml} \text { of extract, } 2 \mathrm{ml} \text { of Wagner's reagent } \\
\text { was added (Iodide in } \mathrm{KI} \text { ) }\end{array}$ & $\begin{array}{l}\text { Reddish brown } \\
\text { coloured precipitated }\end{array}$ \\
\hline Anthraquinones & $\begin{array}{l}\text { Borntrager's } \\
\text { Test }\end{array}$ & $\begin{array}{l}2 \mathrm{ml} \text { of extract was added with } 1 \mathrm{ml} 10 \% \text { ferric } \\
\text { chloride solution and } 1 \mathrm{ml} \text { of conc. } \mathrm{HCl} \text {, } \\
\text { Cooled and filtered. Shake the filtrate with } \\
\text { equal amount of diethyl ether. Further extract } \\
\text { the ether extract with strong } \mathrm{NH}_{3} \text {. }\end{array}$ & $\begin{array}{l}\text { Pink or deep red } \\
\text { coloration of aqueous } \\
\text { layer }\end{array}$ \\
\hline \multirow[t]{2}{*}{ Flavonoides } & $\mathrm{NaOH}$ test & $\begin{array}{l}\text { The extract was treated with dil. } \mathrm{NaOH} \text {, } \\
\text { followed by addition of dilute } \mathrm{HCl} \text {. }\end{array}$ & $\begin{array}{l}\text { A yellow solution with } \\
\mathrm{NaOH} \text {, turns colorless } \\
\text { with dilute } \mathrm{HCl}\end{array}$ \\
\hline & $\begin{array}{l}\text { Lead Acetate } \\
\text { Test }\end{array}$ & $\begin{array}{l}\text { Lead acetate solution was added to a small } \\
\text { quantity of ethanolic extract of test solution. }\end{array}$ & Yellow ppt. \\
\hline \multirow[t]{2}{*}{ Steroids } & $\begin{array}{l}\text { Liebermann- } \\
\text { Burchardt test }\end{array}$ & $\begin{array}{l}\text { To } 1 \mathrm{ml} \text { of methanolic extract, added } 1 \mathrm{ml} \text { of } \\
\text { chloroform, } 2-3 \mathrm{ml} \text { of acetic anhydride, } 1 \text { to } 2 \\
\text { drops of concentrated } \mathrm{H}_{2} \mathrm{SO}_{4} \text {. }\end{array}$ & Dark green coloration \\
\hline & Salkowski test & $\begin{array}{l}5 \mathrm{ml} \text { extract was added with } 2 \mathrm{ml} \text { of chloroform } \\
\text { and } 3 \mathrm{ml} \text { of concentrated sulphuric acid } \mathrm{H}_{2} \mathrm{SO}_{4} \text {. }\end{array}$ & $\begin{array}{l}\text { Reddish brown color } \\
\text { of interface }\end{array}$ \\
\hline \multirow[t]{2}{*}{ Tannins } & Braemer's test & $\begin{array}{l}10 \% \text { alcoholic ferric chloride was added to } 2- \\
3 \mathrm{ml} \text { of methanolic extract }(1: 1)\end{array}$ & $\begin{array}{l}\text { Dark blue or greenish } \\
\text { grey coloration of the } \\
\text { solution }\end{array}$ \\
\hline & Dilute $\mathrm{HNO}_{3}$ & $\begin{array}{l}\text { On addition of dil. } \mathrm{HNO}_{3} \text { solution to the } \\
\text { ethanolic extract }\end{array}$ & Reddish color \\
\hline 6)Terpenoids & $\begin{array}{l}\text { Liebermann- } \\
\text { Burchardt test }\end{array}$ & $\begin{array}{l}\text { To } 1 \mathrm{ml} \text { of methanolic extract, add } 1 \mathrm{ml} \text { of } \\
\text { chloroform, } 2-3 \mathrm{ml} \text { of acetic anhydride, } 1 \text { to } 2 \\
\text { drops of concentrated sulphuric acid. }\end{array}$ & Pink or red coloration \\
\hline
\end{tabular}

Bioassay: The first cleanup fractions 1F1, 1F2, 1F3, 1F4, 1F5, 1F6, 1F7, 1F8, 1F9, and 1F10 from ethyl acetate and methanol crude were used for bioassay with distilled water as control set. Physiological and biochemical tests were then performed with the pre-treated seeds.

\section{ANALYSIS OF PHYSIOLOGICAL PARAMETERS}

Germination behavior: Germination data were recorded every $12 \mathrm{~h}$. intervals up to $120 \mathrm{~h}$. of seed soaking following the International Rules for seed Testing [9]. Seven germination indices, germination percentage (GP), germination index (GI), germination energy (GE), speed of emergence (SE), mean germination time (MGT), seedling vigour index (SVI), and coefficient of the rate/velocity of germination $(\mathrm{CRG})$ were obtained $\&$ then calculated from the same data by using the equations described below (Table-3) . 
TABLE-3: Equations used to calculate Germination indices and other physiological parameters.

\begin{tabular}{|c|c|c|}
\hline $\begin{array}{l}\text { Germination } \\
\text { parameters }\end{array}$ & Equation & Reference \\
\hline $\begin{array}{l}\text { Germination } \\
\text { percent }(G P)\end{array}$ & $\begin{array}{l}\mathrm{GP}=[(\text { number of germinated seeds at final count }) / \text { total number } \\
\text { of seeds sets for bioassay }] \times 100\end{array}$ & Global method \\
\hline $\begin{array}{l}\text { Germination } \\
\text { index }(G l)\end{array}$ & $\mathrm{GI}=\sum \mathrm{G}_{\mathrm{T}} / \mathrm{T}_{\mathrm{t}}$ & AOSA [10] \\
\hline $\begin{array}{l}\text { Mean } \\
\text { germination time } \\
(M G T)\end{array}$ & $\begin{array}{l}\text { MGT }=\left[\sum\left(\mathrm{T}_{\mathrm{i}} \times \mathrm{N}_{\mathrm{i}}\right) / \sum \mathrm{N}_{\mathrm{i}}\right] \\
\mathrm{N}_{\mathrm{i}}=\text { number of newly germinated seeds at time } \mathrm{T}_{\mathrm{i}} .\end{array}$ & Mavi et al. [11] \\
\hline $\begin{array}{l}\text { Seedling vigour } \\
\text { index }(S V I)\end{array}$ & $\mathrm{SVI}=($ seedling length $\times$ germination percent $) / 100$ & Islam et al. [12] \\
\hline $\begin{array}{l}\text { Speed of } \\
\text { emergence }(S E)\end{array}$ & $\begin{array}{l}\mathrm{SE}=(\text { number of germinated seeds at the starting day of } \\
\text { germination/number of germinated seeds at the final day of } \\
\text { measurements }) \times 100\end{array}$ & $\begin{array}{l}\text { Modified from Islam et al. } \\
\text { [12] }\end{array}$ \\
\hline $\begin{array}{l}\text { Germination } \\
\text { energy }(G E)\end{array}$ & $\begin{array}{l}\mathrm{GE}=\text { (percent of germinated seeds at the day of germination/total } \\
\text { number of seeds set for bioassay) } \times 100\end{array}$ & $\begin{array}{l}\text { Modified from Ruan et al. } \\
\text { [13] }\end{array}$ \\
\hline $\begin{array}{l}\text { Coefficient of the } \\
\text { rate of } \\
\text { germination } \\
(C R G)\end{array}$ & $\begin{array}{l}\mathrm{CRG}=\left[\left(\mathrm{N}_{1}+\mathrm{N}_{2}+\ldots \ldots \mathrm{N}_{\mathrm{n}}\right) /\left(\mathrm{N}_{1} * \mathrm{~T}_{1}\right)+\left(\mathrm{N}_{2} * \mathrm{~T}_{2}\right)+\ldots . .\left(\mathrm{N}_{\mathrm{n}} * \mathrm{~T}_{\mathrm{n}}\right)\right]^{*} 100 \\
\text { where, } \mathrm{N}_{1}=\text { number of germinated seeds at time } \mathrm{T}_{1}, \mathrm{~N}_{2}=\text { number of } \\
\text { germinated seeds at time } \mathrm{T}_{2}, \mathrm{~N}_{\mathrm{n}}=\text { number of germinated seeds at } \\
\text { time } \mathrm{T}_{\mathrm{n} .}\end{array}$ & $\begin{array}{l}\text { Bewely and Black [14], } \\
\text { Chiapusio et al. [15] }\end{array}$ \\
\hline Phytotoxicity $(P)$ & $\begin{array}{l}\text { (Root length in control - Root length in treatment)/Root length in } \\
\text { control }\end{array}$ & Chou and Muller, [16] \\
\hline Inhibition (I) & $\begin{array}{l}100-\left(\mathrm{E}_{2} \times 100 / \mathrm{E}_{1}\right), \text { Where } \mathrm{I}=\% \text { Inhibition, } \\
\mathrm{E}_{1}=\text { Response in control, } \mathrm{E}_{2}=\text { Response in treatment plant. }\end{array}$ & Rho \& Kil, [17]. \\
\hline $\begin{array}{l}\text { Relative root } \\
\text { Elongation }\end{array}$ & $\begin{array}{l}\mathrm{R}=(\mathrm{L} / \mathrm{Lr}) \times 100, \text { where } \mathrm{R} \text { is the relative root elongation, } \mathrm{L} \text { is the } \\
\text { mean root length in treatments, } \mathrm{Lr} \text { is mean root length the of } \\
\text { control. }\end{array}$ & Rho \& Kil, [17]. \\
\hline
\end{tabular}

Growth Study: Morphological parameters like root length, shoot length and seedling height were measured in fresh samples after $120 \mathrm{hrs}$. TTC (2, 3, 5-Triphenyl Tetrazolium Chloride) stain ability was done according to the method of Halder [18]. TTC stain ability, were analysed by differential staining pattern, 3 separate categories of seeds (viz., fully stained, partly stained, and not stained) were visually made.

\section{ANALYSIS OF BIOCHEMICAL PARAMETERS}

In the phytotoxicity experiment soluble, insoluble carbohydrate, total free amino acid, protein and cellular respiratory activity were recorded. Soluble and insoluble carbohydrate from seed Kernels was determined following method described by McCready et al, [19]. Quantification of total free amino acid in seed kernel was followed as per the method of Moore and Stein [20] modified by Bhattacharjee [21]. Protein in seed kernels was estimated following the method by Bradford [22] using BSA as standard. The respiratory activity of intact seeds was analysed by the reaction of tetrazolium chloride (TTC) according to the method of Rudrapal and Basu [23].

Statistical Analysis: One-way analysis of variance (ANOVA) followed by Duncan's multiple range test (DMRT) were done for statistical analysis of the data at 5\% level using IBM SPSS v.20. 


\section{RESULTS}

Phytochemical characterization of P. hysterophorus extracts (first cleanup fractions) obtained from ethylacetate and methanolic crude extracts.

The first cleanup fractions (1F1 to $1 \mathrm{~F} 10)$ were tested for qualitative chemical tests for various phytochemical constituents and they confirmed the presence of triterpenes, steroids, alkaloids and flavonoids (Table-4).

TABLE-4: Qualitative phytochemical analysis of chromatographed fractions

\begin{tabular}{|c|c|c|c|c|c|c|c|c|c|c|c|c|c|c|}
\hline $\begin{array}{l}\text { Sl. } \\
\text { No. }\end{array}$ & 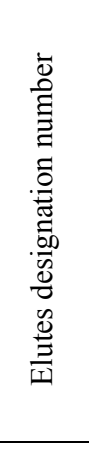 & & $\begin{array}{l}\text { First fraction } \\
\text { elutes. }\end{array}$ & 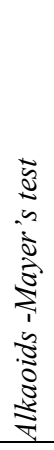 & 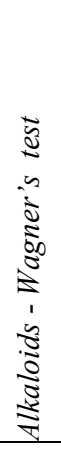 & 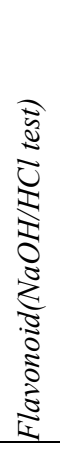 & 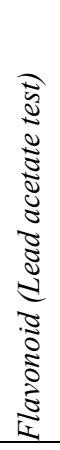 & 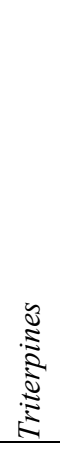 & 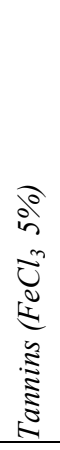 & 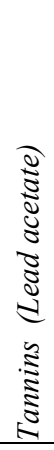 & 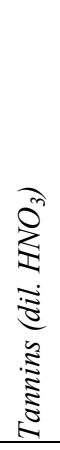 & 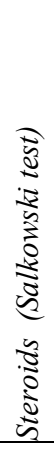 & 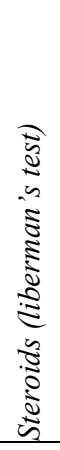 & 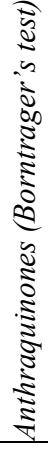 \\
\hline 1. & $1 F 1$ & \multirow{5}{*}{ 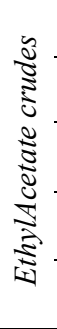 } & Hex elute & - & - & - & - & - & - & - & - & + & - & - \\
\hline 2. & $1 F 2$ & & Hex:EA elute & - & - & - & - & - & - & - & - & - & - & - \\
\hline 3. & $1 F 3$ & & EA elute & - & - & - & - & ++ & - & - & - & + & - & - \\
\hline 4. & $1 F 4$ & & EA:M elute & + & - & - & - & + & - & - & - & + & - & - \\
\hline 5. & $1 F 5$ & & M elute & - & - & + & - & - & - & - & - & - & - & - \\
\hline 6. & $1 F 6$ & \multirow{5}{*}{$\begin{array}{r}\frac{d}{5} \\
\frac{5}{5} \\
\frac{5}{5} \\
\frac{5}{5} \\
\frac{5}{2}\end{array}$} & Hex elute & - & ++ & - & + & ++ & - & - & - & - & - & - \\
\hline 7. & $1 F 7$ & & Hex:EA elute & - & - & - & - & - & - & - & - & + & - & - \\
\hline 8. & $1 F 8$ & & EA elute & - & - & - & - & + & - & - & - & - & - & - \\
\hline 9. & $1 F 9$ & & EA:M elute & - & + & - & + & + & - & - & - & - & - & - \\
\hline 10. & $1 F 10$ & & M elute & - & - & - & + & - & - & + & - & - & - & - \\
\hline
\end{tabular}

Positive tests for terpenoides were indicated for the fractions 1F3, 1F4, 1F6, 1F8 and 1F9 whereas positive for steroids for 1F1, 1F3, 1F4, 1F7 were found. Fractions 1F4, 1F6, 1F9 yield positive for alkaloids and 1F5, 1F6, 1F9, 1F10 for flavonoids. Fraction On the basis of the above results all the fractions were selected for phytotoxicity bioassay.

Effect of P. hysterophorus extracts (first cleanup fractions) on germination and growth of $V$. radiata

There is a significant change in germination parameters of ethyl acetate and methanol fractions (Figure-1). In methanolic fractions 1F6, 1F7, 1F8, 1F9, 1F10 the kinetics are much lower in comparison to control.

The ethylacetate fractions (Table-5) have significant $(\mathrm{P}<0.05)$ effect on all calculated germination indices. The GP, GI, CRG, SE, GE, SVI showed a reduced trend in 1F3, 1F4, followed by $1 \mathrm{~F} 2$ and 1F1 except MGT. 

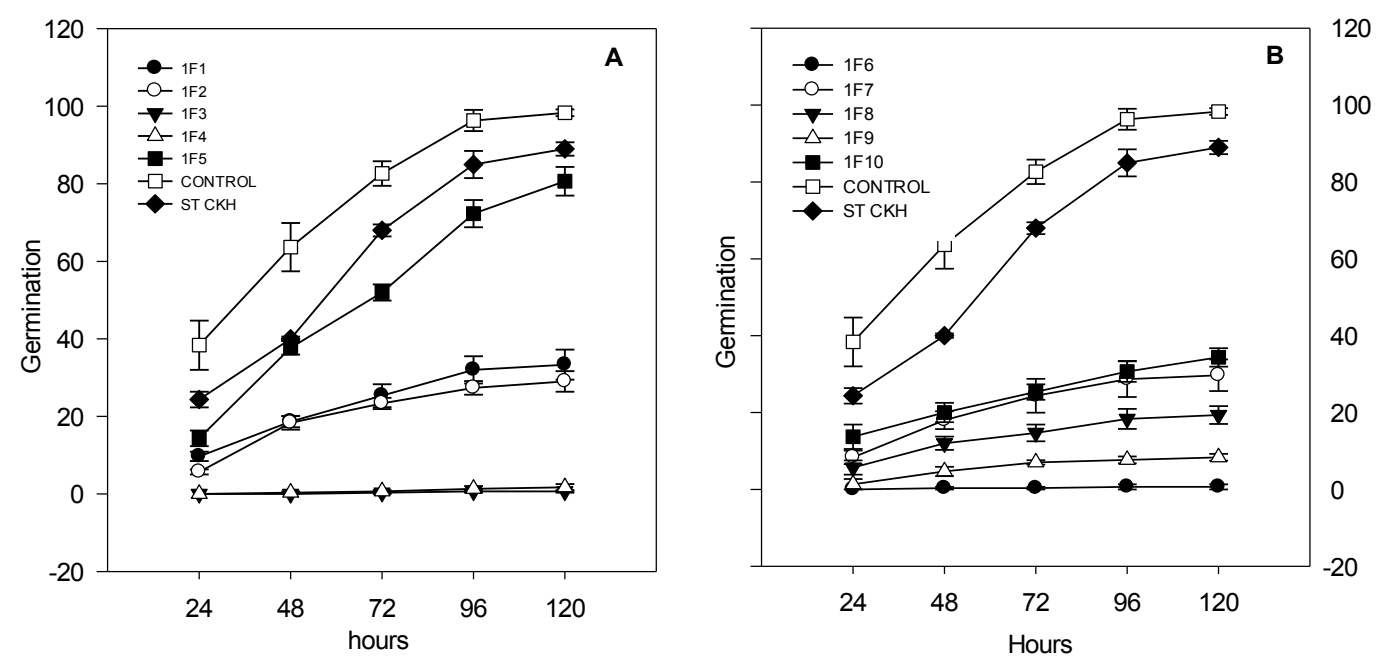

FIGURE-1: Germination kinetics of Vigna seeds treated with first clean-up fractions (A- ethylacetate fractions; Bmethanol fractions)

The methanol fractions (Table-6) also have significant $(\mathrm{P}<0.05)$ effect on all calculated germination indices. The GP, GI, CRG, SE, GE, SVI decreased in 1F6, 1F9, followed by 1F8, 1F7, and 1F10 except MGT, which is increased.

TABLE-5: Effect of ethylacetate crude cleanup fractions of Parthenium on germination:

\begin{tabular}{llllllll}
\hline Treatments & $G P$ & $G I$ & $M G T$ & $C R G$ & $S E$ & $G E$ & $S V I$ \\
\hline 1F1 & $33.33^{\mathrm{d}}$ & $18.32^{\mathrm{d}}$ & $2.40^{\mathrm{a}}$ & $42.08^{\mathrm{a}}$ & $29.81^{\mathrm{ab}}$ & $33.33^{\mathrm{d}}$ & $5.44^{\mathrm{c}}$ \\
1F2 & $29.00^{\mathrm{d}}$ & $15.00^{\mathrm{d}}$ & $2.41^{\mathrm{a}}$ & $41.58^{\mathrm{a}}$ & $19.90^{\mathrm{bc}}$ & $29.00^{\mathrm{d}}$ & $5.89^{\mathrm{c}}$ \\
1F3 & $0.67^{\mathrm{e}}$ & $0.19^{\mathrm{e}}$ & $2.33^{\mathrm{a}}$ & $19.44^{\mathrm{b}}$ & $0.00^{\mathrm{d}}$ & $0.67^{\mathrm{e}}$ & $0.05^{\mathrm{c}}$ \\
1F4 & $1.67^{\mathrm{e}}$ & $0.51^{\mathrm{e}}$ & $2.39^{\mathrm{a}}$ & $18.61^{\mathrm{b}}$ & $0.00^{\mathrm{d}}$ & $1.67^{\mathrm{e}}$ & $0.20^{\mathrm{c}}$ \\
1F5 & $80.67^{\mathrm{c}}$ & $37.53^{\mathrm{c}}$ & $2.82^{\mathrm{a}}$ & $35.54^{\mathrm{ab}}$ & $17.66^{\mathrm{c}}$ & $80.67^{\mathrm{c}}$ & $9.05^{\mathrm{c}}$ \\
CONTROL & $98.33^{\mathrm{a}}$ & $61.15^{\mathrm{a}}$ & $2.14^{\mathrm{a}}$ & $47.32^{\mathrm{a}}$ & $39.02^{\mathrm{a}}$ & $98.33^{\mathrm{a}}$ & $69.30^{\mathrm{a}}$ \\
ST CHK & $89.00^{\mathrm{b}}$ & $46.55^{\mathrm{b}}$ & $2.56^{\mathrm{a}}$ & $39.12^{\mathrm{a}}$ & $27.32^{\mathrm{bc}}$ & $89.00^{\mathrm{b}}$ & $43.74^{\mathrm{b}}$ \\
\hline
\end{tabular}

Data are mean of three replicates; different superscripts in a column indicate significant difference at $P<0.05$.

TABLE-6: Effect of methanol crude cleanup fractions of parthenium on germination:

\begin{tabular}{llllllll}
\hline Treatments & $G P$ & $G I$ & $M G T$ & $C R G$ & $S E$ & $G E$ & $S V I$ \\
\hline 1F6 & $0.67^{\mathrm{f}}$ & $0.25^{\mathrm{f}}$ & $3.00^{\mathrm{a}}$ & $11.11^{\mathrm{b}}$ & $0.00^{\mathrm{b}}$ & $0.67^{\mathrm{f}}$ & $0.21^{\mathrm{d}}$ \\
1F7 & $29.67^{\mathrm{c}}$ & $16.56^{\mathrm{cd}}$ & $2.35^{\mathrm{b}}$ & $42.73^{\mathrm{a}}$ & $27.74^{\mathrm{a}}$ & $29.67^{\mathrm{c}}$ & $2.43^{\mathrm{d}}$ \\
1F8 & $19.33^{\mathrm{d}}$ & $10.84^{\mathrm{de}}$ & $2.36^{\mathrm{b}}$ & $42.45^{\mathrm{a}}$ & $31.79^{\mathrm{a}}$ & $19.33^{\mathrm{d}}$ & $6.96^{\mathrm{d}}$ \\
1F9 & $8.33^{\mathrm{e}}$ & $4.08^{\mathrm{ef}}$ & $2.55^{\mathrm{b}}$ & $39.55^{\mathrm{a}}$ & $13.33^{\mathrm{b}}$ & $8.33^{\mathrm{e}}$ & $1.52^{\mathrm{d}}$ \\
1F10 & $34.33^{\mathrm{c}}$ & $20.68^{\mathrm{c}}$ & $2.40^{\mathrm{b}}$ & $41.97^{\mathrm{a}}$ & $39.37^{\mathrm{a}}$ & $34.33^{\mathrm{c}}$ & $20.06^{\mathrm{c}}$ \\
CONTROL & $98.33^{\mathrm{a}}$ & $61.15^{\mathrm{a}}$ & $2.14^{\mathrm{b}}$ & $47.32^{\mathrm{a}}$ & $39.02^{\mathrm{a}}$ & $98.33^{\mathrm{a}}$ & $73.25^{\mathrm{a}}$ \\
ST CHK & $89.00^{\mathrm{b}}$ & $46.55^{\mathrm{b}}$ & $2.56^{\mathrm{b}}$ & $39.12^{\mathrm{a}}$ & $27.32^{\mathrm{a}}$ & $89.00^{\mathrm{b}}$ & $43.74^{\mathrm{b}}$ \\
\hline
\end{tabular}

Data are mean of three replicates; different superscripts in a column indicate significant difference at $P<0.05$.

Ethylacetate fractions, 1F3, 1F4 and 1F5 shows maximum inhibitory effect on the root and shoot growth of the test species followed by $1 \mathrm{~F} 1$ and 1F2 (Figure-2A). The maximum root, shoot and seedling growth was inhibited by $1 \mathrm{~F} 3$ fraction; while the minimum inhibition was noted for 1F2 fraction. Methanol fractions 1F7 shows maximum inhibitory effect on root and shoot growth of germinating Vigna seeds (Figure-2B). 

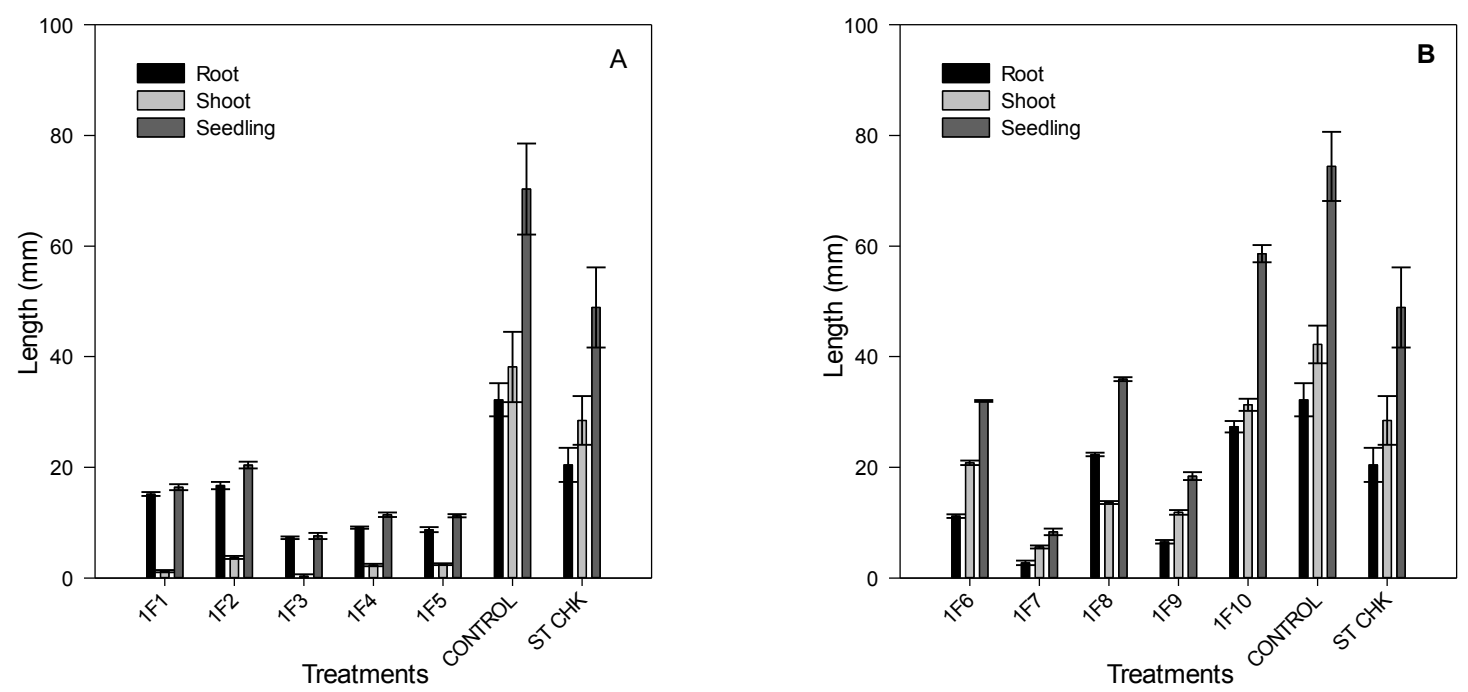

FIGURE-2: Effect of first clean-up fractions on growth of Vigna radiata (A-ethylacetate fractions; B- methanol fractions)

The toxicity potential of ethylacetate and methanol extracts was also supported by phytotoxicity, inhibition and relative root elongation (Figure-3A,B). The cleanup fractions 1F3, 1F4, 1F6, 1F9 and 1F7 shows significant $(\mathrm{P}<0.05)$ toxicity on growth of test species. The strong phytotoxicity, inhibitiory activity and least root elongation was noted for 1F3, 1F4, 1F6, 1F9 fraction; whereas minimal toxicity potential were observed in 1F5, 1F8, 1F10. TTC staining pattern and TTC stainability (Table-7-8) reveals a significant effect of the fractions on Vigna seeds germination. Fraction 1F4, 1F2 and 1F6 shows minimum TTC stainability of 81,82 and $85 \%$ respectively. Overall TTC stainability was reduced in all treatments in comparison to control.
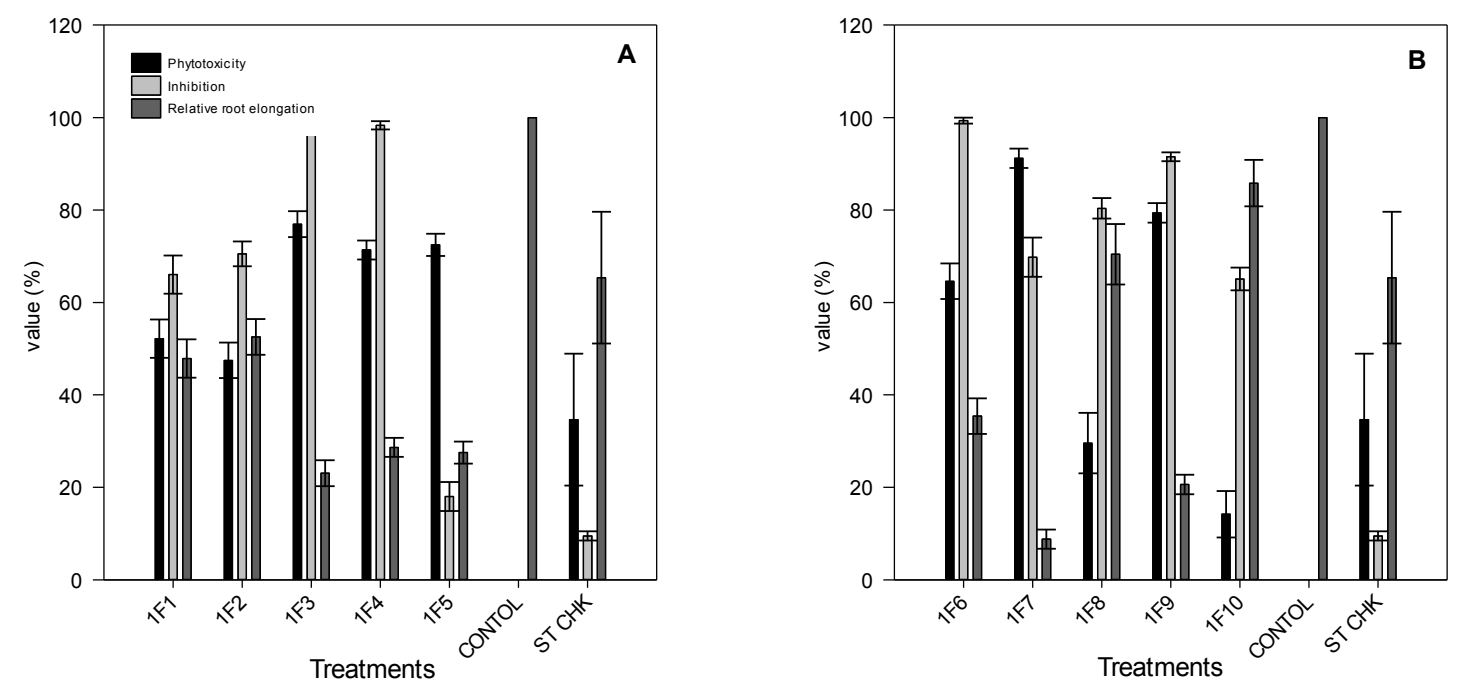

FIGURE-3: Effect of first clean-up fractions on Phytotoxicity, inhibition and relative root elongation of Vigna (Aethylacetate fractions; B- methanoli fractions) 
TABLE-7: Effect of ethylacetate crude cleanup fractions of on seed health:

\begin{tabular}{ccccc}
\hline Treatments & Full stained & Partly stained & Not stained & TTC stained (\%) \\
\hline 1F1 & $90.33^{\mathrm{a}}$ & $1.67^{\mathrm{c}}$ & $8.00^{\mathrm{bc}}$ & $92.00^{\mathrm{ab}}$ \\
1F2 & $62.00^{\mathrm{bc}}$ & $20.33^{\mathrm{ab}}$ & $17.67^{\mathrm{ab}}$ & $82.33^{\mathrm{bc}}$ \\
1F3 & $70.00^{\mathrm{b}}$ & $24.33^{\mathrm{a}}$ & $5.67^{\mathrm{c}}$ & $94.33^{\mathrm{a}}$ \\
1F4 & $55.00^{\mathrm{c}}$ & $26.33^{\mathrm{a}}$ & $18.67^{\mathrm{a}}$ & $81.33^{\mathrm{c}}$ \\
1F5 & $87.67^{\mathrm{a}}$ & $10.33^{\mathrm{bc}}$ & $2.00^{\mathrm{c}}$ & $98.00^{\mathrm{a}}$ \\
CONTROL & $93.33^{\mathrm{a}}$ & $5.00^{\mathrm{c}}$ & $1.67^{\mathrm{c}}$ & $98.33^{\mathrm{a}}$ \\
ST CHK & $62.00^{\mathrm{bc}}$ & $27.00^{\mathrm{a}}$ & $11.00^{\mathrm{abc}}$ & $89.00^{\mathrm{abc}}$ \\
\hline
\end{tabular}

Data are mean of three replicates; different superscripts in a column indicate significant difference at $P<0.05$.

TABLE-8: Effect of methanol crude cleanup fractions of on seed health:

\begin{tabular}{ccccc}
\hline Treatments & Full stained & Partly stained & Not stained & TTC stained (\%) \\
\hline 1F6 & $61.33^{\mathrm{b}}$ & $23.67^{\mathrm{a}}$ & $15.00^{\mathrm{a}}$ & $85.00^{\mathrm{c}}$ \\
1F7 & $84.33^{\mathrm{a}}$ & $7.67^{\mathrm{b}}$ & $8.00^{\mathrm{abc}}$ & $92.00^{\mathrm{abc}}$ \\
1F8 & $85.00^{\mathrm{a}}$ & $9.67^{\mathrm{b}}$ & $5.33^{\mathrm{bc}}$ & $94.67^{\mathrm{ab}}$ \\
1F9 & $87.33^{\mathrm{a}}$ & $5.67^{\mathrm{b}}$ & $7.00^{\mathrm{bc}}$ & $93.00^{\mathrm{ab}}$ \\
1F10 & $93.33^{\mathrm{a}}$ & $3.67^{\mathrm{b}}$ & $3.00^{\mathrm{c}}$ & $97.00^{\mathrm{a}}$ \\
CONTROL & $93.33^{\mathrm{a}}$ & $5.00^{\mathrm{b}}$ & $1.67^{\mathrm{c}}$ & $98.33^{\mathrm{a}}$ \\
ST CHK & $62.00^{\mathrm{b}}$ & $27.00^{\mathrm{a}}$ & $11.00^{\mathrm{ab}}$ & $89.00^{\mathrm{bc}}$ \\
\hline Data are mean of three replicates; different superscripts in a column indicate significant difference at $P<0.05$
\end{tabular}

\section{Effect of ethyl acetate and methanolic fractions on biochemical parameters of germinating Vigna seeds:}

The Biochemical component (Table-9-10) shows high soluble carbohydrate in 1F3 and 1F6 treatments (11.46 $\mathrm{mg} \mathrm{g}^{-1}$ and $9.76 \mathrm{mg} \mathrm{g}^{-1}$ fresh weight respectively) followed by 1F2, 1F9. On the contrary, insoluble carbohydrate at highest quantity was noted in 1F4, 1F3 and 1F6 treatments (260.14, 245.77 and $248 \mathrm{mg} \mathrm{g}^{-1}$ fresh weight respectively). Total free aminoacids follows the same pattern as soluble carbohydrate. Cellular respiration measured through formazan percent were drastically reduced in $1 \mathrm{~F} 3,1 \mathrm{~F} 6,1 \mathrm{~F} 9$, and $1 \mathrm{~F} 4$ treatments.

TABLE-9: Effect of ethyl acetate fractions on biochemical parameters of mungbeans:

\begin{tabular}{|c|c|c|c|c|c|}
\hline Treatments & $\begin{array}{c}\text { Soluble } \\
\text { Carbohydrate } \\
\text { (mg } g^{-1} \text { fresh } \\
\text { weight) }\end{array}$ & $\begin{array}{c}\text { Insoluble } \\
\text { Carbohydrate } \\
\text { (mg } g^{-1} \text { fresh } \\
\text { weight) }\end{array}$ & $\begin{array}{c}\text { Total Free } \\
\text { Amino Acids } \\
\text { (mg } g^{-1} \text { fresh } \\
\text { weight) }\end{array}$ & $\begin{array}{c}\text { Cellular } \\
\text { Respiration } \\
(\%)\end{array}$ & $\begin{array}{c}\text { Total } \\
\text { protein } \\
\left(\mathrm{mg}^{-1} \text { fresh }\right. \\
\text { weight })\end{array}$ \\
\hline $1 \mathrm{~F} 1$ & $6.61^{b}$ & $172.73^{b}$ & $3.57^{\mathrm{ab}}$ & $79.92^{\mathrm{ab}}$ & $125.70^{\mathrm{a}}$ \\
\hline $1 \mathrm{~F} 2$ & $7.92^{\mathrm{b}}$ & $89.36^{\mathrm{cd}}$ & $0.79^{\mathrm{d}}$ & $82.93^{\mathrm{ab}}$ & $90.30^{b c}$ \\
\hline $1 \mathrm{~F} 3$ & $11.46^{\mathrm{b}}$ & $245.77^{\mathrm{a}}$ & $4.06^{\mathrm{a}}$ & $36.87^{\mathrm{c}}$ & $74.00^{\mathrm{bcd}}$ \\
\hline $1 \mathrm{~F} 4$ & $7.22^{\mathrm{b}}$ & $260.14^{\mathrm{a}}$ & $1.20^{\mathrm{d}}$ & $48.25^{\mathrm{c}}$ & $98.97^{\mathrm{ab}}$ \\
\hline $1 \mathrm{~F} 5$ & $7.34^{\mathrm{b}}$ & $86.09^{\mathrm{C}}$ & $1.73^{\mathrm{cd}}$ & $76.19^{b}$ & $59.88^{\mathrm{d}}$ \\
\hline CONTROL & $7.48^{\mathrm{b}}$ & $31.24^{\mathrm{d}}$ & $0.83^{\mathrm{d}}$ & $100.00^{\mathrm{a}}$ & $48.42^{\mathrm{d}}$ \\
\hline ST CHK & $6.92^{\mathrm{b}}$ & $53.46^{\mathrm{cd}}$ & $2.56^{\mathrm{bc}}$ & $99.89^{\mathrm{a}}$ & $66.85^{\mathrm{cd}}$ \\
\hline
\end{tabular}

Data are mean of three replicates; different superscripts in a column indicate significant difference at $P<0.05$.

TABLE-10: Effect of methanol fractions on biochemical parameters of mungbeans:

\begin{tabular}{|c|c|c|c|c|c|}
\hline Treatments & $\begin{array}{c}\text { Soluble } \\
\text { Carbohydrate } \\
\text { (mg } \mathrm{g}^{-1} \text { fresh } \\
\text { weight) }\end{array}$ & $\begin{array}{c}\text { Insoluble } \\
\text { Carbohydrate } \\
\text { (mg } g^{-1} \text { fresh } \\
\text { weight) }\end{array}$ & $\begin{array}{c}\text { Total Free } \\
\text { Amino Acids } \\
\text { (mg } g^{-1} \text { fresh } \\
\text { weight) }\end{array}$ & $\begin{array}{c}\text { Cellular } \\
\text { Respiration } \\
(\%)\end{array}$ & $\begin{array}{c}\text { Total } \\
\text { protein } \\
\text { (mg } g^{-1} \text { fresh } \\
\text { weight) }\end{array}$ \\
\hline $1 \mathrm{~F} 6$ & $9.76^{\mathrm{a}}$ & $248.80^{\mathrm{a}}$ & $4.91^{\mathrm{a}}$ & $26.93^{c}$ & $58.61^{\mathrm{de}}$ \\
\hline $1 \mathrm{~F} 7$ & $5.80^{\mathrm{bc}}$ & $148.49^{b c}$ & $3.18^{b}$ & $64.27^{\mathrm{b}}$ & $106.67^{\mathrm{b}}$ \\
\hline $1 \mathrm{~F} 8$ & $7.26^{\mathrm{bc}}$ & $97.83^{\mathrm{cd}}$ & $2.99^{b}$ & $56.03^{\mathrm{b}}$ & $122.48^{\mathrm{a}}$ \\
\hline $1 \mathrm{~F} 9$ & $7.59^{\mathrm{b}}$ & $167.75^{\mathrm{b}}$ & $4.53^{\mathrm{a}}$ & $31.79^{c}$ & $84.42^{\mathrm{c}}$ \\
\hline $1 \mathrm{~F} 10$ & $5.50^{\mathrm{c}}$ & $67.05^{\mathrm{de}}$ & $1.78^{\mathrm{c}}$ & $66.95^{\mathrm{b}}$ & $84.42^{\mathrm{c}}$ \\
\hline CONTROL & $7.48^{b}$ & $31.24^{\mathrm{e}}$ & $0.83^{\mathrm{d}}$ & $100.00^{\mathrm{a}}$ & $48.42^{\mathrm{e}}$ \\
\hline ST CHK & $6.92^{b c}$ & $53.46^{\mathrm{de}}$ & $2.56^{\mathrm{bc}}$ & $99.89^{\mathrm{a}}$ & $66.85^{\mathrm{d}}$ \\
\hline
\end{tabular}

Data are mean of three replicates; different superscripts in a column indicate significant difference at $P<0.05$. 


\section{DISCUSSION}

Presence of terpenoides, streroides, flavonoids, tannins and alkaloids in the ethylacetate and methanol elutes are in agreement with the findings of [24-35].

Gross allelopathic potential of $P$. hysterophorus, revealed from the seed germination bioassay. Among the ethylacetate and methanol extracts, 1F3, 1F4 elutes from ethylacetate and 1F6, 1F9 elutes from methanol fraction indicates a significant inhibitory response on seed germination as also explained from the germination indices. Overall the extract (1F3, 1F4, 1F6, 1F9) reduces germinability and slows down germination kinetics which is considered to be the important visible and reliable indices for the evaluation of allelopathic Effect. Germination percent (GP) index indicated the total germination percent of a seed lot after certain period of time $(120 \mathrm{~h}$.) when germination became constant. As it is measured by total germination relative to total number of seeds set for germination, GP alone cannot explain the delayed germination. In contrast, GI is a measure of both percentage and speed of germination and assigns maximum arithmetic weight to seeds that germinate during first count and less weight to those that germinate later. The higher the GI, GE, SE, SVI, and CRG values compared to control, the lower the inhibition, and vice versa, except for MGT [36]. On the other hand, mean germination time (MGT) was calculated as the weighted mean of germination time. The number of seeds germinated in the interval of time is used as weight. Here the use of weighted mean is extremely important as it considers that a different number of seeds germinate in the interval of time [c.f. 37]. Hence, MGT is proportional to reduced and poor germinability. The delay or inhibition of germination caused by phytotoxic plant extracts or substances was also reported by Anjum et al [38] and Hussain et al. [39] as also corroborated by Tefera [5], Regina et al. [40], Rashid et al, [41], Dhole and Dhole [42]. Similar trends of germination retardation were also reported by Marwat et al [43] in Avena fatua and Lepidium pinnatifidum. The data thus indicating a strong allelopathic effect.

Respiratory ability were also reduced in these treatments over other treatments. These results are in strong agreement with Batish et. al. [44]. Abrahim [45] reported that interference of monoterpenes with respiratory ability can lead to germination and growth retardation. Cellular metabolic activity in terms of sugar, total protein, total free amino acids were also impared in the four treatments (1F3, 1F4, 1F6, and 1F9). Similar type of observation were also recorded by Kiran et al. [46], Padhy et al. [47].

\section{CONCLUSION}

The present study concluded that phytotoxicity of four fractions $(1 F 3,1 F 4,1 F 6$, and $1 F 9)$ from ethylacetate and methanolic crude extracts of Parthenium hysterophorus could be exploited as potential bioherbicide for future weed management programme and the development of bioherbicide for commercial use.

\section{References}

[1] Adityachaudhury, N., Bhattaacharyya, A., Chowdhury, A. and Pal, S., (1985). Chemical Constituents of Plants Exhibiting Insecticidal, Antifeedants and Insect Growth Regulating Activities. Journal of Scientific and Industrial Research, 44, 85-101.

[2] Vyvyan, J. R. Allelochemicals as leads for new herbicides and agrochemicals. Tetrahedron, 58 (2002) 1631-1646.

[3] Dayan, F.E., Romagni, J.G., Duke, S.O. (2000). Investigating the mode of natural phytotoxins. Journal of Chemical Ecology, 26(9): 2079-2094.

[4] Dayan, F.E.; Cantrell, C.L.; Duke, S.O. Natural products in crop protection. Bioorg. Med. Chem. (2009), 17, 4022-4034. 
[5] Tefera, T. Allelopathic effects of Parthenium hysterophorus extracts on seed germination and seedling growth of Eragrostis tef. Journal of Agronomy and Crop Science, 188 (2002) 306310 .

[6] Pati, U.K., Chowdhury, A. (2015). A comparision of phytotoxic potential among the crude extracts from Parthenium hysterophorus L. extracted solvents of increasing polarity. International Letters of Natural Sciences. 33: 73-81.

[7] Kanchan, S.D., Jayachandra, 1980. Allelopathic effects of Parthenium hysterophorus L. IV. Identification of inhibitors. Pl. Soil 55, 67-75.

[8] Harborne, J. B. (1998). Phytochemical Methods: A guide to modern technique of plant analysis. Chapman and Hall, London.

[9] International Seed Testing Association. (2008). International Rules for Seed Testing. International. Seed Testing Association, Bassersdorf, Switzerland.

[10] Association of Official Seed Analysis (AOSA), Seed Vigor Testing Handbook, Handbook on Seed Testing, Contribution no. 32, 1983.

[11] Mavi, K., Demir, I., Matthews, S. (2010) Mean germination time estimates the relative emergence of seed lots of three cucurbit crops under stress conditions. Seed Sci. and Technol. $38: 14-25$.

[12] Islam, A. K. M. A., Anuar, N. and Yaakob, Z. Effect of genotypes and pre-sowing treatments on seed germination behavior of Jatropha. Asian Journal of Plant Sciences, vol. 8, no. 6, pp. 433-439, 2009.

[13] Ruan, S., Xue, Q., and Tylkowska, K. The influence of priming on germination of rice (Oryza sativa L.) seeds and seedling emergence and performance in flooded soil. Seed Science and Technology, vol. 30, no. 1 (2002) pp. 61-67.

[14] Bewley, J.D. and Black, M. Seeds: Physiology of Development and Germination, Plenum Press, NewYork, NY, USA, 1985.

[15] Chiapusio, G., S'anchez, A. M., Reigosa, M. J., Gonz'alez, L., and Pellissier, F., (1997). Do germination indices adequately reflect allelochemical effects on the germination process?. Journal of Chemical Ecology, (23)11, pp. 2445-2453.

[16] Chou, C.H., and Muller, C.H. Allelopathic mechanism of Archtostaphylons glandulosa var. Zazensis. Am Mid Nat 88 (1972) 329-347.

[17] Rho, B.J., and Kil, B.S. Influence of phytotoxin from Pinus rigida on the selected plants. $J$. Nat. Sci. Wonkwang Univ. 5 (1986) 19-27.

[18] Halder, S. (1981). Studies on viability, yield and associated biochemical changes in leaves during seed filling in sunflower (Helianthus annuus L. cv. EC 68414). Ph. D. Thesis, Burdwan University, West Bengal, India.

[19] McCready, R. M., Guggloz, J., Silviera, V. and Owens, J. S. (1950). Deterioration of starch and amylase in vegetables. Analytical Chemistry, 22:1156-1158.

[20] Moore, S. and Stein, W. W. Photometric ninhydrin method for use in the chromatography of amino acids. Journal of Biological Chemistry, 176 (1948) 367-388.

[21] Bhattacharjee, A. and Gupta, K. (1984). Differential responses of sunflower (Helianthus annuus cv. Morden) towards high and low concentrations of dikegulac-sodium. Can. J. Bot. 62: 495-500.

[22] Bradford, M.M. (1976). A rapid and sensitive method for the quantitative of microgram quantities of protein utilizing the principle of protein-Dye binding. Ann. Biochem. 2:248-254. 
[23] Rudrapal, A. B. and Basu, R. N. Physiology of hydration-dehydration treatments in the maintenance of seed viability in wheat. Indian Journal of Experimental Biology. 17 (1979) 768-771.

[24] Das, R., Geethangili, M., Majhi, A., Das, B., Rao, Y.K. and Tzeng, Y.M. (2005). A new highly oxygenated pseudoguaianolide from a collection of the flowers of Parthenium hysterophorus. Chemical and Pharmaceutical Bulletin (Tokyo) 53: 861-862.

[25] Das, B., Mahender, G., Rao, Y.K., Ramesh, C., Venkateswarlu, K., Ravikumar, K., Geethangili, M., Tzeng, Y.M. (2006). Pseudoguaianolides from the Flowers of Parthenium hysterophorus. Helvetica Chimica Acta 89: 285-290.

[26] Das, B., Reddy, V.S., Krishnaiah, M., Sharma, A.V., Ravi Kumar, K., Rao, J.V., Sridhar V. (2007). Acetylated pseudoguaianolides from Parthenium hysterophorus and their cytotoxic activity. Phytochemistry 68: 2029-2034.

[27] Das, B., Reddy, K.R., Ravikanth, B., Sharma, A.V.S., Sridhar, B. (2008). Two new pseudoguanolide from the flower of Parthenium hysterophorus. Helvetica Chimica Acta 91: 1137-1143.

[28] Rodriguez, E., Yoshioka, H. and Marby, T.J. (1971). The sesquiterpene lactone chemistry of the genus Parthenium (Compositae). Phytochemistry 10: 1145-1154.

[29] Rodriguez, E. (1977). Ecogeographic distribution of secondary constituents in Parthenium (Compositae). Biochemical Systematics and Ecology 5: 207-218.

[30] Towers, G.H.N., Mitchell, J.C., Rodriguez, E., Bennett, F.D. and Subbarao, P.V. (1977). Biology and chemistry of Parthenium hysterophorus L., a problem weed in India. Journal of Scientific and Industrial Research 36: 672-684.

[31] Picman, A.K., Towers, G.H.N. and Rao, P.V.S. 1980. Coronopilin - another major sesquiterpene lactone in Parthenium hysterophorus. Phytochemistry 19: 2206-2207.

[32] Picman, A.K., Balza, F. and Towers, G.H.N. 1982. Occurrence of hysterin and dihydroisoparthenin in Parthenium hysterophorus. Phytochemistry (Oxford) 21: 1801-1802.

[33] Picman, A. K. 1986. Biological activities of sesquiterpene lactones. Biochem. Syst. Ecol. $14: 255-281$.

[34] Ramesh, C., Ravindranath, N., Das, B., Prabhakar, A., Bharatam, J., Ravikumar, K. Kashinatham, A. and McMorris, T.C. Pseudoguanolides from the flowers of Parthenium hysterophorus. Phytochemistry, 64 (2003) 841-844.

[35] Venkataiah, B., Ramesh, C., Ravindranath, N. and Das, B. (2003). Charminarone, a secopseudoguaianolide from Parthenium hysterophorus. Phytochemistry 63: 383-386.

[36] Islam, A.K.M.M., Kato-Noguchi, H., (2014). Phytotoxic activity of Ocimum tenuiflorum extracts on germination and seedling growth of different plant species. http://dx.doi.org/10.1155/2014/676242

[37] Ranal, M.A., and Santana, D.G.D. (2006). How and why to measure the germination process?. Revista Brasil. Bot. 29(1), 1-11.

[38] Anjum, T. and Bajwa, R. Importance of germination indices in interpretation of allelochemical effects. International Journal of Agriculture and Biology, vol. 7, pp. 417-419, 2005.

[39] Hussain, M. I., Gonzalez-Rodriguez, L., and Reigosa, M. J., (2008) Germination and growth response of four plant species to different allelochemicals and herbicides, Allelopathy Journal, (22)1, 101-110. 
[40] Regina, G.B., C.F. Reinhardtb, L.C. Foxcroftc and K. Hurlea. Residue allelopathy in Parthenium hysterophorus L.-Does parthenin play a leading role? Crop Protection, 26 (2007) 237-245.

[41] Rashid, H., Khan, M.A., Amin, A., Nawab, K., Hussain, N. and Bhowmik, P.K. (2008) Effect of Parthenium hysterophorus L., root extracts on seed germination and growth of maize and barley. The Americas J. Plant Sci. Biotech., 2(2): 51-55.

[42] Dhole JA, Bodke, S.S. and Dhole, N.A. Allelopathic effect of aqueous leaf extract of Parthenium hysterophorus L. on seed germination and seedling emergence of some cultivated crops. Journal of research in Biology 1 (2011) 15-18.

[43] Marwat, K.B., Khan, M.A., Nawaz, A., Amin, A., (2008). Parthenium hysterophorus L. A potential source of bioherbicide. Pak. J. Bot., 40(5):1933-1942.

[44] Batish, D.R., Setia, N., Singh, H.P., Kohli, R.K., 2004. Phytotoxicity of lemon-scented eucalypt oil and its potential use as a bioherbicide. Crop Protection, 23, 1209-1214.

[45] Abranim, D., Braguini, W.L., Kelmer Bracht, A.M., Ishi-IwaMoto, E.L., (2000). Effects of four monoterpenes on germination, primary root growth and mitochondrial respiration of maize. J. Chem. Ecol. 26, 611-623.

[46] Kiran, C.R., Rao, D.B., Sirisha, N., Rao, T.R. Impact of Germination on Biochemical and Antioxidant Enzymes of Ceiba pentandra (Kapok) Seeds, American Journal of Plant Sciences. 3 (2012) 1187-1192.

[47] Padhy, B., Patnaik, P.K., and Tripathy, A.K. (2000). Allelopathic potential of Eucalyptus leaf litter leachates on germination and seedling growth of finger millet. Allelopathy Journal, 7(1), 69-78. 